\title{
PROCESSABILITY THEORY AND PEDAGOGICAL PROGRESSION IN AN ITALIAN TEXTBOOK
}

\section{INTRODUCTION}

Second language acquisition (= SLA) research has the potential to contribute a great deal to the pedagogical question of how language instruction should be organized to fit best the learner's actual capacities and needs. In order to fully exploit this potential, we need to understand how the knowledge of a language develops from very basic knowledge to intermediate and high knowledge. This understanding will enable us to focus our attention on the learner's level of ability and to optimize teaching methods and syllabi. Furthermore, since language instruction is often based on a textbook, a better understanding of language acquisition will have substantial effects on textbook design.

This paper attempts to contribute to the abovementioned field of SLA research. As such it is grounded in Processability Theory (= PT; Pienemann 1998; 2005), whose declared objective is to determine the developmental sequences of procedural skills in learners.

In the underlying empirical research, I analyse the grammatical structures and their progression in an Italian-language textbook for beginners (Brambilla/Crotti/Von Albertini 2003) and compare the findings then to the speaking ability of learners who have been taught using that textbook to cross-check the degree of correspondence between what is taught following the textbook and what is actually learned. If - as PT predicts - learners can only acquire structures belonging to the stage immediately following the stage they have already achieved, it is questionable whether it makes sense to focus on structures of higher stages during the learning process. I am therefore convinced that such research should be promoted and that its findings should be considered crucial for syllabus and for textbook design as well.

To start, in section 2 some information about the theoretical background of this research is given. Section 3 then moves to present the data and to explain the methodology. In section 4 the data is analysed, whereas in section 5 the results of the analysis are shown. Section 6 then provides some discussion and concluding remarks.

\footnotetext{
* Author's address: Institut für Sprachen und Literaturen, Innrain 52, A-6020 Innsbruck, Austria. Email: Katharina.Zipser@uibk.ac.at
} 


\section{THEORETICAL BACKGROUND - PROCESSABILITY THEORY}

The present research is grounded in Processability Theory (= PT; Pienemann 1998; 2005). PT in turn mainly draws on two theories, (1) Levelt's Theory of Speaking (Levelt 1989 ; 1998) to account for how knowledge is accessed and processed for output, and (2) Bresnan's Lexical Functional Grammar (Bresnan 1982; 2001) to describe interlanguage knowledge.

Pienemann himself assumes that learners can only acquire forms which they can process, and he predicts that "in the acquisition of language processing procedures, the assembly of the component parts will follow an implicational sequence" (Pienemann 1998: 6). This means that language acquisition develops in stages, with structures of larger volume and greater complexity requiring a greater exchange of information and longer storage before exchange. So, higher stages entail an increase in processing demands. The stages vary slightly from language to language.

\subsection{Stages of acquisition for Italian L2}

Di Biase/Bettoni (2007) develop a table which illustrates the stages of acquisition for Italian as an L2. This table (see below, Di Biase/Bettoni 2007: 212) is based on longitudinal studies of children in primary schools with L2-programs (Di Biase 2002):

\begin{tabular}{|c|c|c|c|c|}
\hline & procedure & $\begin{array}{l}\text { information } \\
\text { exchange }\end{array}$ & morphosyntax & examples \\
\hline stage 5 & $\begin{array}{l}\text { S-bar } \\
\text { procedure }\end{array}$ & interclausal & $\begin{array}{l}\text { main clause and } \\
\text { subordinate clause } \\
\text { with subjunctive }\end{array}$ & $\begin{array}{l}\text { d'accordo, Tommasino, } \\
\text { purché le mangi dopo* }\end{array}$ \\
\hline \multirow{2}{*}{ stage 4} & \multirow{2}{*}{ S-procedure } & \multirow{2}{*}{ interphrasal } & $\begin{array}{l}\text { agreement between subj } \\
\& \text { predicative adjective }\end{array}$ & le mele sono buone \\
\hline & & & $\begin{array}{l}\text { agreement between subj } \\
\text { \& VP }\end{array}$ & i orsi mangiano le mele \\
\hline \multirow{2}{*}{ stage 3} & \multirow{2}{*}{$\begin{array}{l}\text { phrasal } \\
\text { procedure }\end{array}$} & \multirow{2}{*}{ phrasal } & agreement within VP & sono buoni \\
\hline & & & agreement within NP & tutti buoni \\
\hline \multirow{3}{*}{ stage 2} & \multirow{3}{*}{$\begin{array}{l}\text { categorial } \\
\text { procedure }\end{array}$} & \multirow{3}{*}{ none } & person marking on $\mathrm{V}$ & mangia - mangi \\
\hline & & & past tense marking on $\mathrm{V}$ & mangia - mangiato \\
\hline & & & plural marking on $\mathrm{N}$ & bambino - bambini \\
\hline stage 1 & word/lemma & none & single words and chunks & $\begin{array}{l}\text { Io mi chiamo Thomas; } \\
\text { bambino, mela }\end{array}$ \\
\hline
\end{tabular}

Figure 1: Stages of acquisition for Italian L2 (translated Zipser).

The first procedure acquired is that of lexical access. Lexical items are retrieved from the mental lexicon in response to conceptual content. At this stage, the items are 
simply juxtaposed, no information is exchanged between them. In the right column some examples are given: simple words such as bambino ('child'), mela ('apple') ... and unanalyzed chunks such as Io mi chiamo Thomas ('My name is Thomas').

At stage 2, words are added to the target lexicon, and their grammatical category is assigned. At this level, learners of Italian are able to build plural forms regardless of the noun's gender, i.e., to form bambino - bambini ('child' - 'children'), to form the past participle, i.e., mangiare - mangiato ('eat' - 'eaten') and to mark the person on the verb mangio, mangi ('I eat', 'you eat'), etc.

Stage 3 enables phrasal exchange, which means that from this stage on there is agreement within nominal and verbal phrases, e.g., tutti buoni ('all good'), sono buoni ('they are good').

Stage 4 shows evidence for interphrasal agreement (i.e., agreement between different phrases). Ergo a learner at this stage can implement agreement between subject and predicate, e.g., $i$ orsi mangiano le mele ('The bears eat the apples') and between subject and predicative adjective, e.g., Le mele sono buone ('The apples are good'). (NB: Agreement between subject and predicate does not provide clear proof for interphrasal agreement. Plural marking on the verb could also be explained by a categorial procedure which is already possible at stage 2. (see also Di Biase/Bettoni 2007: 214)).

At stage 5 (the highest stage of acquisition for Italian) interclausal agreement between a principal clause and a subordinate clause containing subjunctive is found.

\section{DATA AND METHODOLOGY}

Data was collected by analysing the grammatical structures in an Italian textbook for beginners and by eliciting oral speech production in learners of Italian as an L2.

Firstly, Buongiorno! Neu. Italienisch für Anfänger (Brambilla/Crotti/Von Albertini 2003) - used in many Austrian secondary schools as well as in adult education - was selected for textbook analysis. It emphasises the communicative aspect of language and the importance of perceiving language in its specific cultural context. By the end of a course based on this book, students should have reached A2 level according to the Common European Framework of Reference (= CEFR), which means that they should be able to cope successfully with everyday situations. Succeeding in this requires a certain vocabulary and certain grammatical structures, which are introduced in the textbook according to the communicative needs.

Secondly, some speech performance of Austrian L2 learners of Italian (aged between 19 and 35 and attending an evening school for business) was elicited for oral speech analysis. At the time of the data elicitation the first 10 units (out of 17) had been covered in class. Students were interviewed at the beginning of their third semester, at which point they had had two semesters of Italian with three 45-minute lessons per week (i.e., 90 hours of instruction received).

The empirical study was organized as follows: First, the morphosyntactic structures of the textbook (Brambilla/Crotti/Von Albertini 2003) on which the learner's attention is focused during a course were surveyed. The structures actually counted were those found in the grammar section of the appendix of the book, i.e., the structure to 
be explicitly taught per unit (Brambilla/Crotti/Von Albertini 2003: 164-208). It was analysed at which stage - according to PT - the different morphosyntactic structures can be acquired and if these structures are arranged gradually in the textbook. The spontaneous oral production of L2-learners of Italian whose Italian course was based on the book was analysed in parallel in order to see which stages of acquisition their productions fall into.

\section{ANALYSIS OF THE DATA}

\subsection{Textbook - data}

The aim of the textbook analysis was to see which stage of acquisition is required to actively build and use the several structures of the textbook which were explicitly presented to be taught. For this part of the study, all morphosyntactic structures of the grammar section were considered (Brambilla/Crotti/Von Albertini 2003: 164-208).

The following examples are some of the sentences found:

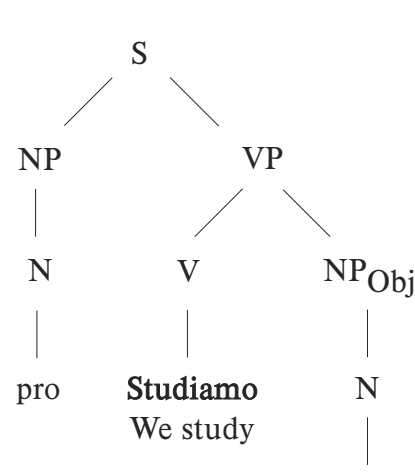

informatica computer science
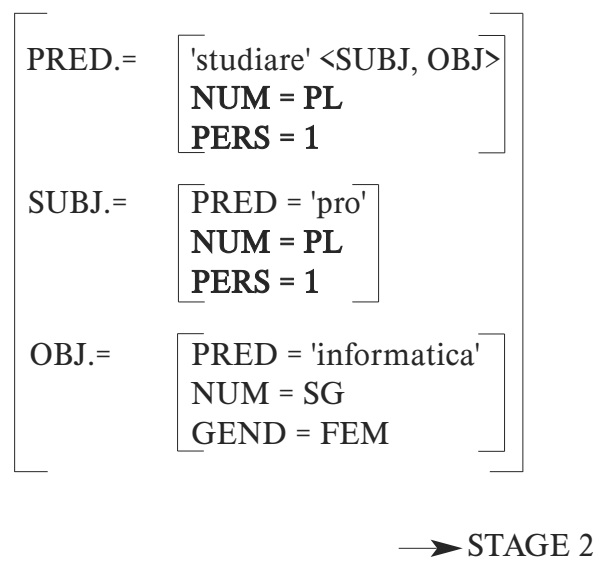

Figure 2: c-structure and f-structure for Studiamo informatica.

The constituent structure of this sentence (c-structure) contains the lexical categories verb and noun, but does not contain any functional category. The verb and the noun merge and create the verbal phrase. The functional structure (f-structure) contains the predicate studiamo ('we study'), a transitive verb in first person plural, and the direct object informatica ('computer science'). To produce this structure, it is necessary to mark the verb with the suffix -iamo which contains the information both for first person and plural in the pro-drop language Italian. According to Di Biase/Bettoni 2007 learners are able to implement such utterances at stage 2 .

A higher stage of acquisition is necessary to produce the sentence Fuma troppe sigarette. 

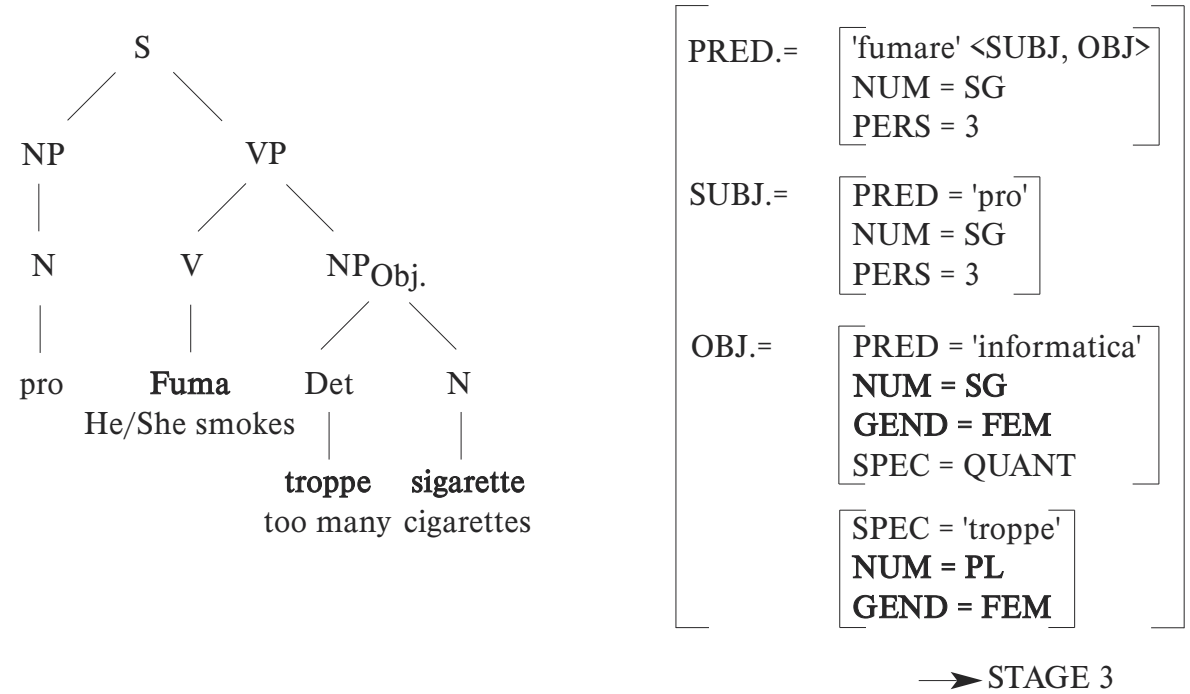

Figure 3: c-structure and f-structure for Fuma troppe sigarette.

The c-structure of this sentence contains the lexical categories verb and noun and the functional category determiner. The determiner and the noun merge to form the nominal phrase. The nominal phrase represents the direct object, since fumare ('smoke') is a transitive verb. The f-structure shows exactly this; it shows that the predicate fuma ('smoke') is third person singular and transitive and that its object is represented by troppe sigarette ('too many cigarettes'), a noun specified by a quantifier. To implement this structure (troppe sigarette), the feminine value of the gender feature and the plural value of the number feature must be stored, checked and exchanged.

The next sentence is an example for stage 4 .
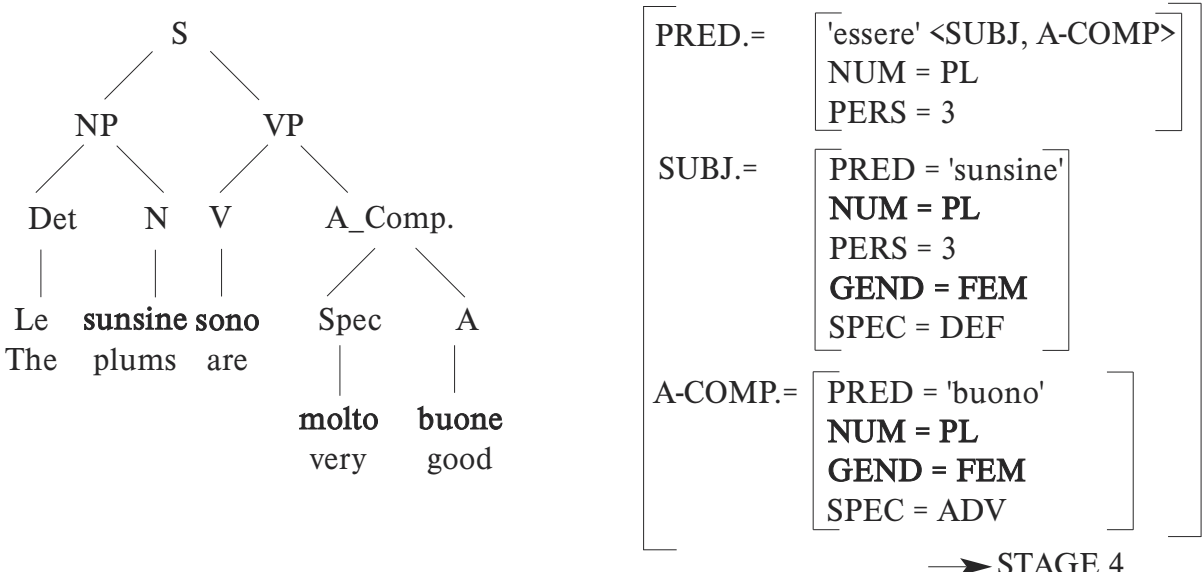

Figure 4: c-structure and f-structure for Le susine sono molto buone. 
This sentence is composed of the nominal phrase le susine ('the plums') and a verbal phrase sono molto buone ('are very good'). Its c-structure contains the lexical categories noun, verb, adverb and adjective and the functional category determiner. The determiner le ('the') and the noun susine ('plums') merge to form the nominal phrase. The adjective complement composed of the adverb molto ('very') and the adjective buone ('good') fuses with the verb sono ('are') to build the verbal phrase. Subject, predicate and adjective complement characterize the f-structure of this sentence. As the values of the number feature (plural), the person feature (third person) and the gender feature (feminine) show, there is information exchange between the subject le susine ('the plums') and the subject complement sono molto buone ('are very good'). Actually there is agreement between the two elements susine (f. P1.) and buone (f. P1.) in gender (f.) and number (Pl.). Since the production requires interphrasal exchange learners must have reached stage 4 to formulate such an utterance.

Stage 5 is reached when learners are able to produce structures containing principal clause and subordinate clause with subjunctive (Di Biase/Bettoni 2007). However, although the sentence I will present next does not contain a subjunctive, it is rather complex and seems to require a stage higher than 4 .

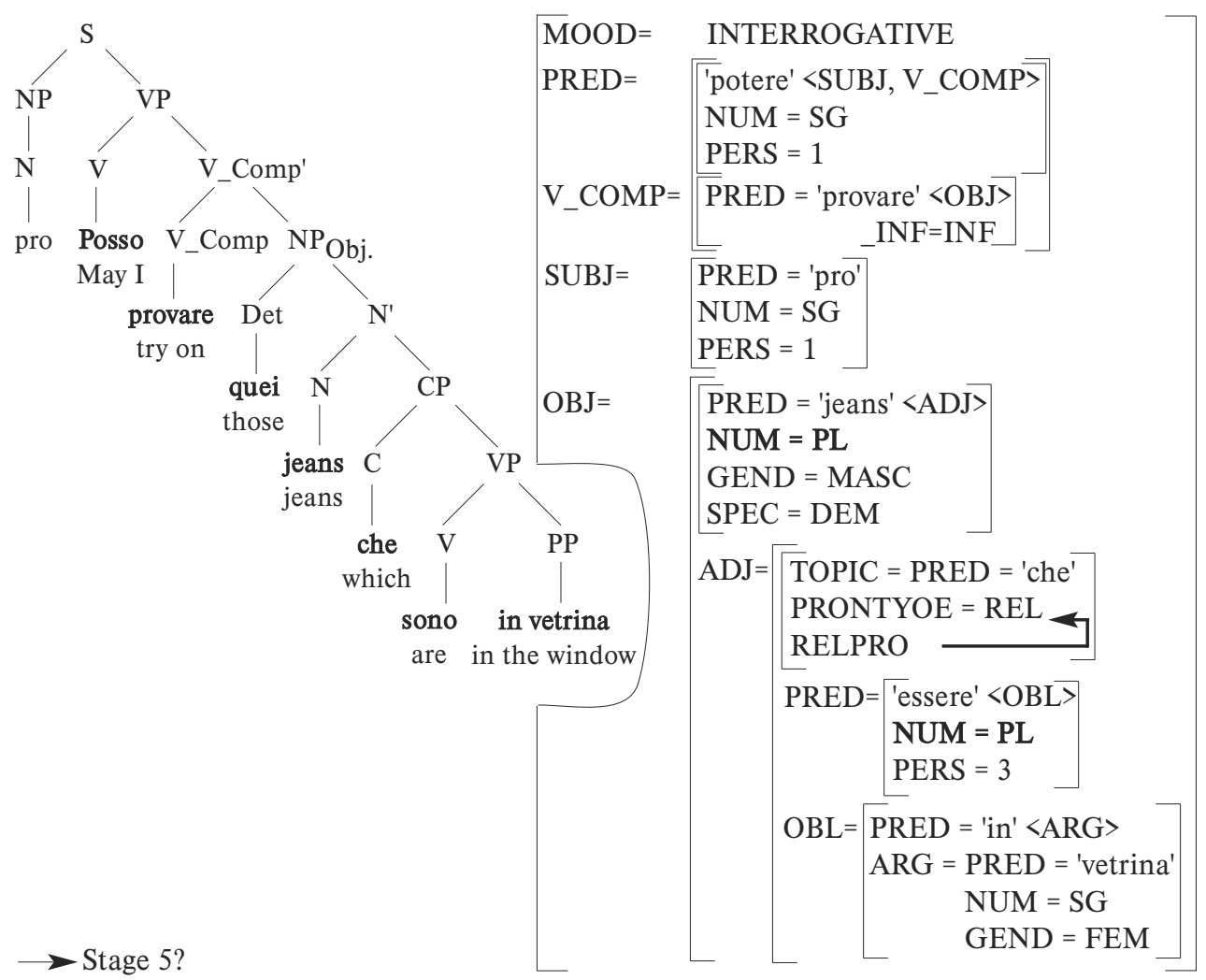

Figure 5: c-structure and f-structure for Posso provare quei jeans che sono in vetrina? 
This interrogative clause, besides the fact that there is a verbal complement depending on the main verb posso ('may'), contains another particularity. It contains a relative clause introduced by the pronoun che ('which'). Its c-structure shows that the verbal phrase contains a verb and a verbal complement and that the infinitive provare ('try on') c-commands the phrase quei jeans che sono in vetrina ('those jeans which are in the window'). Within its nominal phrase the noun jeans ('jeans') is specified by a complementizer phrase. The f-structure of this sentence contains a predicate and a direct object. The direct object is represented by a noun specified by a demonstrative pronoun and an adjunct. The adjunct itself is represented by the relative pronoun che ('which'), the predicate sono ('are') and the oblique in vetrina ('in the window'), which can be separated into preposition and noun. Uttering this interrogative clause requires unification between the main clause's direct object quei jeans ('those jeans') and the verbal phrase of the subordinate clause. The learner must store the value of the number feature in jeans ('jeans'), the main phrase's direct object, and check it against that of sono ('are'), the subordinate clause's predicate. This means that not only the ability to store and exchange information within the phrase but also interclausal information exchange is required. The information exchange takes place between the main and the relative clause. The fact that the production of relative clauses is rather difficult for L1 learners has already been shown by an empirical study done by Guasti/Cardinaletti in 2003: For Romance languages they assume that "children learn relative pronouns and thus pied-piping relatives only during school years, through explicit teaching" (Guasti/Cardinaletti 2003: 47).

In the following, the total distribution of structures requiring the stages 1 to 5 is revealed by a quantitative analysis of the grammar section. The development of structures requiring the various stages is shown in percentages in the following diagram.

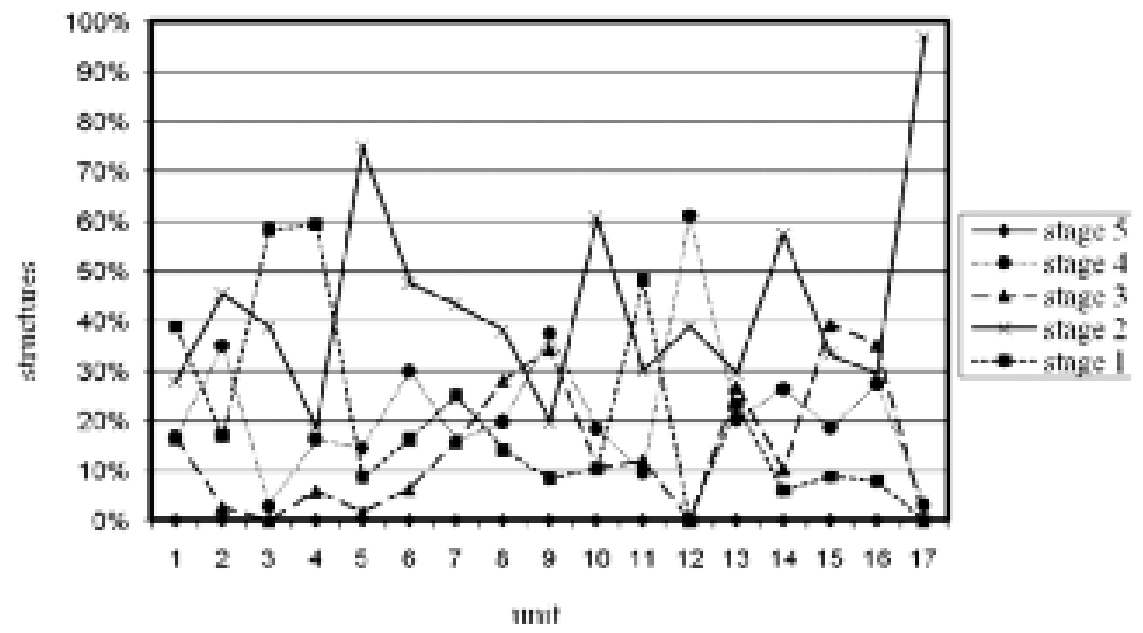

Figure 6: Stages in Buongiorno! neu (unit 1-17) 
The $\mathrm{x}$-axis depicts the units of the book from 1 to 17 whereas the $\mathrm{y}$-axis displays the percentage distribution of structures requiring stage 1 to stage 5 for each unit. Thus the diagram as a whole shows the progression of the five stages (stage 1 to 5) from unit 1 to 17 . The highest percentage for stage 1 is reached in unit 4: 60\% of all structures of this unit require stage 1, i.e., more than the half of the target structures of these lectures are just words to be learnt as for example numbers, day names and month names, etc. There is a rather low percentage for stage 2 in the first units, while in unit 5, 10 and 14 more than $50 \%$ of the structures require this stage. The highest percentage of structures requiring stage 3 is located in unit 9,15 and 16, while there are hardly any such structures in units 2, 3, 4, 5, 6 and 12 . Most structures requiring stage 4 are located in 2, 6, 9 and 12 . The book contains none of the structures that are usually considered to be at stage five. (It does, however, contain some sentences with relative clauses: By analysing the interrogative clause Posso provare quei jeans che sono in vetrina? I tried to show that producing this kind of structure seems to require a stage higher than 4 , since not only interphrasal information exchange but also interclausal information exchange must take place. Although there are no empirical results to prove this hypothesis and further research is needed, relative clauses seem to be difficult - even for L1 learners.) All in all, it is noteworthy that the distribution of structures requiring stage 1 to 5 is rather random. Nevertheless, most structures of the first eight units require only stage 1 to 3 .

The pie chart below gives an idea of the percentage distribution of structures requiring stage 1 to 5 in Buongiorno! Neu and demonstrates their total percentages:

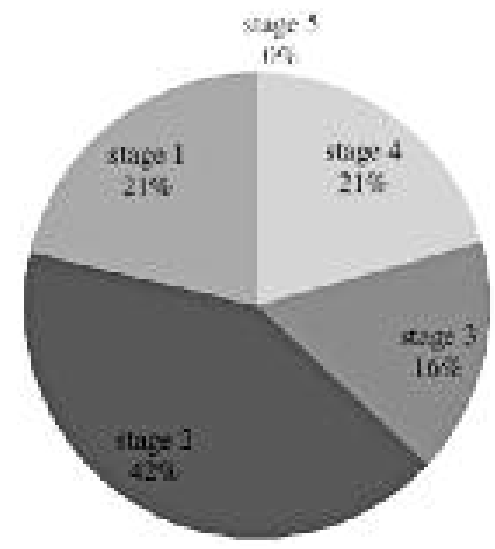

Figure 7: Percentage of stage 1, 2, 3, 4, 5 in unit 1-17.

As can be seen, $21 \%$ of all structures require stage $1 ; 42 \%$ require stage $2 ; 16 \%$ require stage 3 and $21 \%$ require stage 4 .

\subsection{Oral speech production}

With this we come to the second part of data analysis of this study, the analysis of oral speech production. Oral speech production was elicited by two picture stories 
(Frog, where are you? [Mayer 1969] and a picture story in which the daily routine of an Italian woman is shown).

The tables below exemplarily show the results of my analysis of the oral production of four students. The resulting raw frequency counts have been interpreted on the basis of the emergence criterion for acquisition: According to e.g., Di Biase (1999) there is enough evidence for a stage to be acquired if a learner applies a rule in 3 out of 4 produced contexts $(\rightarrow 75 \%)$. For instance, student 1 seems to have reached stage 3 as he was able to apply rules of stage 3 level with a rate of $86 \%$. The second diagram shows the results for student 1 in a more detailed way: As can be observed, he had difficulty marking the person on the verb.

\begin{tabular}{|l|l|c|c|c|c|}
\hline & & student 1 & student 2 & student 3 & student 4 \\
\hline stage 5 & inter-clausal & $/$ & $/$ & $/$ & $/$ \\
\hline stage 4 & interphrasal processes & $(+/-)$ & $+^{*}$ & + & $+^{*}$ \\
\hline stage 3 & phrasal processes & + & $(+/-)$ & + & $(+/-)$ \\
\hline stage 2 & lexical processes & + & $(+/-)$ & + & $(+/-)$ \\
\hline stage 1 & words (undifferentiated) & + & + & + & + \\
\hline
\end{tabular}

Table 1: Global results for student 1, 2, 3 and 4.

/no evidence, i.e. no linguistic contexts

- context is produced but rule is not applied

$(+)$ insufficient evidence of rule application, or formulaic use only, or echo effect

$(+/-)$ various contexts are produced with non-application and occasional, insufficient, evidence of application

+ sufficient evidence, i.e. evidence for rule application in the presence of contexts

+* NB: structures showing agreement between subject \& predicative adjective were considered as were structures containing a subject and a predicate. The latter are no clear proof for interphrasal agreement as the marking on the verb could also be motivated by a categorical procedure (stage 2).

\begin{tabular}{|l|l|c|}
\hline & morphosyntax & total \\
\hline stage 5 & main clause \& subordinate clause with subjunctive & $/$ \\
\hline \multirow{2}{*}{ stage 4 } & agreement between subj. \& predicative adjective & $/$ \\
\cline { 2 - 3 } & agreement between subj. \& VP & $(+/-)$ \\
\hline \multirow{2}{*}{ stage 3 } & agreement within VP & + \\
\cline { 2 - 3 } & agreement within NP & $+(-)$ \\
\hline \multirow{3}{*}{ stage 2 } & person marking on V & + \\
\cline { 2 - 3 } & past tense marking on V & + \\
\cline { 2 - 3 } & plural marking on N & + \\
\hline \multirow{2}{*}{ stage 1 } & word/lemma & + \\
\hline
\end{tabular}

Table 2: Detailed results for student 1. 
For each learner and structure, a '+' marks structures which have been acquired according to the emergence criterion of PT (rule applied in 3 out of 4 cases, $\rightarrow 75 \%$ ): there were linguistic contexts and sufficient evidence for rule application. A ' ' means that there were no linguistic contexts for the application of the rule, i.e. there was no evidence. A ' $(+)$ ' marks insufficient evidence for rule application, formulaic use or echo effect, while '(+/-)' means that there were various contexts produced with nonapplication and occasional insufficient evidence of application. It seems peculiar that student 2 and 4 were able to produce structures requiring stage 4 while they were not able to properly apply the rules associated with stage 2 and 3 . This might be justified by the rather small amount of data. However, it has to be clarified that most stage 4 structures they produced are of the type 'subject - verb - object' with agreement between subject and verb, whereas the students produced hardly any stage 4 structures requiring agreement between subject and predicative adjective. This raises the question whether the criterion of rule application with a rate of $75 \%$ is enough to guarantee that a stage is acquired or whether data should show sufficient evidence for application of all corresponding rules. Structures with agreement between subject and verb do not clearly prove interphrasal exchange: the marking on the verb could also be motivated categorically as was already stated in chapter 2.1. If there was a distinction between structures with subject-verb agreement and structures with agreement between subject and predicative adjective, then student 2 and 4 would have obtained the emergence criterion for one type of stage 4 structures but they would not have reached it for the other one. In any case, it can be shown that they produce structures requiring stage 2 and 3 even if various contexts are produced with non-application and occasional insufficient evidence of application.

\section{RESULTS AND DISCUSSION}

The results of this study provide strong evidence in support of the notion that there is a specific sequential development in the acquisition of Italian morphosyntax. As shown, not all structures are sufficiently attested. This does not falsify the hypothesised sequential development but might be caused at least in part by the relatively small amount of data. The briefly mentioned difficulty with structure 4 could probably be resolved by distinguishing between two different subtypes, but this requires further research. Furthermore, it must be explained why the students are not as good as we might suggest in formulating stage 2 and stage 3 structures. It is possible that the implicational scale for Italian must be reviewed and probably be modified further.

One question of interest which in any case remains is whether the content of textbooks should be arranged according to the natural sequence of interlanguage development. The analysis of the textbook in question demonstrated that it is not sequenced according to the natural sequence of interlanguage development, but that the distribution of structures is rather random. Furthermore, the analysis showed that there is hardly any distinction between input, intake and learning objectives, as students are expected to produce an output that is similar to their input. The obtained data demonstrates also that students are not able to process grammatical structures 
that rank high in the Processability hierarchy. This is because the necessary prerequisites to process these structures are not available right at the beginning of their acquisition process. In keeping with Processability Theory, this means that although the students might well be able to reproduce structures from higher levels as rote-learned formulae, they cannot use them productively in different contexts.

Before I actually conclude, let me briefly mention a further difficulty in class. Besides the fact that a learner is ready only to acquire structures from the next stage ('Teachability Hypothesis', see Pienemann 1984; 1988; 1998: 250), (1) every single learner is an individual and favors different learning methods and (2) a group of students will always be heterogeneous, as the rate of acquisition is individual (see e.g., Lightbown 2000). This causes a further difficulty in language teaching, since a teacher has to take every student's individual readiness and every student's needs into account. A qualitative textbook should therefore support teachers in catering to the heterogeneous needs of students in their class and equip them with appropriate exercises and tasks.

\section{CONCLUSION}

Most learners in a classroom environment are taught a language on the basis of a textbook, which normally provides a guideline for them and their teachers. Designing and writing textbooks is hard work, and it is equally difficult to choose the book which best fits the learners' needs and engages their interest. Learners will achieve best results if motivated, but no matter how motivated they are, they will not be able to acquire grammatical structures ranking high in the Processability hierarchy at all times. In order to prevent frustration and disappointment in teachers and to support and foster learners in the best possible way, it is important to understand the process of language learning.

It is therefore reasoned that since natural input will always contain structures that fall into the next-higher stage for each individual student, instruction need not be sequenced. Nonetheless, teachers should distinguish between input, intake and expected output, i.e., learning objectives. They cannot expect students to produce all types of structures they use at all times. The same is valid for textbook design. In every single unit of every textbook there will be acquirable structures for each individual learner, but no learner will automatically acquire and be capable of actively using a structure upon seeing it presented for the first time. Therefore textbook authors and publishers should be sensitive to the language learning process and should incorporate a distinction between input and learning objectives within the design of their textbooks.

\section{References}

Brambilla, Rosanna/Alessandra Crotti/Lucia Von Albertini (2003) Buongiorno! Neu. Italienisch für Anfänger. Wien: öbv\&hpt Klett.

BRESNAN, Joan (2001) Lexical-Functional Syntax. Malden/Massachusetts: Blackwell. Chini, Marina/Paola Desideri/Anna De Meo/Gabriele Pallotti (eds) (2007) Imparare una Lingua. Recenti Sviluppi Teorici e Proposte Applicative. Perugia: Guerra Edizioni. 
Di BiASE, Bruno (1999) "The Acquisition of Inflectional Morphology in Learners of Italian L2 with some Reference to the Rule of Phonological Word Structure." Paper presented at EUROSLA 9, June 1999, Lund (Sweden).

Di BIASE, Bruno (2002) Developing a Second Language. Acquisition, Processing and Pedagogy of Arabic, Chinese, English, Italian, Japanese, Swedish. Melbourne: Language Australia.

Di BIASE, Bruno (2002) "Focusing Strategies in Second Language Development: A Classroom-based Study of Italian L2 in Primary School.” In: B. Di Biase (ed), 95-111.

Di BiASe, Bruno/Camilla BetToni (2007) "Funzioni Discorsive e Processabilità in Italiano L2." In: M. Chini/P. Desideri/A. De Meo/G. Pallotti (eds), 209-233.

GuASTI, Maria Teresa/Anna CARDINALETTI (2003) "Relative Clause Formation in Romance Child's Production." Probus 15, 47-89.

Lightbown, Patsy M. (2000) "Anniversary article. Classroom SLA Research and Second Language Teaching." Applied Linguistics 21/4, 431-462.

Levelt, Willem J. M. (1998) Speaking. From Intention to Articulation. Cambridge/Massachusetts/London et al.: MIT Press.

MAYER, Mercer (1969) Frog, Where are You? New York: Dial Books.

Pienemann, Manfred (1984) "Psychological Constraints on the Teachability of Languages." Studies in Second Language Acquisition 6/2, 186-214.

Pienemann, Manfred (1998) Language Processing and Second Language Development. Processability Theory. Amsterdam/Philadelphia: John Benjamins.

Pienemann, Manfred (2005) Cross-Linguistic Aspects of Processability Theory. Amsterdam/Philadelphia: John Benjamins.

Pienemann, Manfred/Jürgen Keßler (2011) Studying Processability Theory. An Introductory Textbook. Amsterdam/Philadelphia: John Benjamins.

SELINKER, Larry (1972) "Interlanguage." IRAL 10, 209-231.

$\begin{array}{ll}\text { ABBREVIATIONS } \\ \text { A } & \text { adjective } \\ \text { A_Comp } & \text { adjective complement } \\ \text { Adj } & \text { adjunct } \\ \text { adv } & \text { adverb } \\ \text { Arg } & \text { argument } \\ \text { C } & \text { complementizer } \\ \text { CP } & \text { complementizer phrase } \\ \text { c-structure } & \text { constituent structure } \\ \text { def } & \text { definite } \\ \text { dem } & \text { demonstrative } \\ \text { Det } & \text { determiner } \\ \text { fem } & \text { feminine } \\ \text { f-structure } & \text { functional structure } \\ \text { Gen } & \text { gender } \\ \text { _Inf } & \text { inflection }\end{array}$




$\begin{array}{ll}\text { Inf } & \text { infinitive } \\ \text { masc } & \text { masculine } \\ \text { N } & \text { noun } \\ \text { NP } & \text { nominal phrase } \\ \text { Num } & \text { number } \\ \text { Obj } & \text { object } \\ \text { Obl } & \text { oblique } \\ \text { P } & \text { preposition } \\ \text { Pers } & \text { person } \\ \text { Pl } & \text { plural } \\ \text { PP } & \text { prepositional phrase } \\ \text { Pred } & \text { predicate } \\ \text { PT } & \text { Processability Theory } \\ \text { quant } & \text { quantifier } \\ \text { Rel } & \text { relative (clause) } \\ \text { S } & \text { sentence } \\ \text { Sg } & \text { singular } \\ \text { SLA } & \text { Second Language Acquisition } \\ \text { Spec } & \text { specifier } \\ \text { Subj } & \text { subject } \\ \text { V } & \text { verb } \\ \text { V_Comp } & \text { verbal complement } \\ \text { VP } & \text { verbal phrase }\end{array}$

\section{Abstract \\ PROCESSABILITY THEORY AND PEDAGOGICAL PROGRESSION IN AN ITALIAN TEXTBOOK}

Most L2-learners are taught a language on the basis of a textbook. But are these textbooks arranged according to the learners' needs? For the present study the grammatical structures and their progression in an Italian-language textbook were analysed, and they were compared to the learners' speaking ability to cross-check the degree of correspondence between what is taught following the textbook and what is actually learned. The question is asked in how far textbook design should consider the findings of current SLA research. It is suggested that even though Processability Theory is right to predict that language acquisition develops in stages, instruction need not be strictly sequenced. Above all it is important to distinguish between input, intake and expected output.

Keywords: language acquisition, textbook design, Processability Theory, interlanguage, language proficiency. 


\section{Povzetek \\ TEORIJA STOPENJSKOSTI USVAJANJA JEZIKA IN PODAJANJE SNOVI V UČBENIKU ZA ITALIJANŠČINO}

Večina nematernih govorcev se jezika uči s pomočjo učbenika, kar odpira vprašanje, ali obstoječi učbeniki ustrezajo dejanskim potrebam učencev. Zato smo v pričujoči raziskavi analizirali slovnične strukture in njihovo podajanje v učbeniku italijanščine, nato pa smo jih primerjali z jezikovnimi zmožnostmi učencev, da bi ugotovili stopnjo prekrivanja med metodo učenja in usvojenim znanjem. Rezultati študije odpirajo vprašanje, v kolikšni meri bi morali učbeniki upoštevati spoznanja na področju usvajanja jezikov. Čeprav teorija stopenjskosti usvajanja jezika ugotavlja, da se jezikovna zmožnost razvija po etapah, namreč ni nujno, da je na ta način podana tudi snov v učbenikih. Najpomembnejše je namreč razločevati med vhodnimi informacijami, izhodnimi informacijami in dejansko usvojenim znanjem.

Ključne besede: usvajanje jezika, načrtovanje učbenikov, teorija stopenjskosti usvajanja jezika, medjezikovno, jezikovna zmožnost. 